\title{
PERCEPTION AND UNDERSTANDING OF AGRICULTURAL EXTENSION: PERSPECTIVE OF FARMERS AND PUBLIC AGRICULTURAL EXTENSION IN THABA NCHU
}

\author{
Cloete, P. ${ }^{1}$, Bahta, Y. T. ${ }^{2}$, Marunga, M. ${ }^{3}$ and Lombard, W. A. ${ }^{4}$ \\ Correspondence author: W. A. Lombard. Email: LombardWA@ufs.ac.za
}

\begin{abstract}
Agriculture is a backbone for the overall development of Africa. It is widely acknowledged that the small-scale farmers need empowerment through extension services to achieve the National Development Plan of South Africa. The aim of this paper is to improve the understanding of different role players on the concept of agricultural extension service in South Africa. This study concentrated on the rarely assessed different role players' concept of extension service, especially farmers and agricultural extension officers with respect to the objective of extension, agricultural extension principles, extension teaching, and methods teaching aids and tools. The results found that a general mismatch exists between farmers and agricultural extension officers on the conceptualisation of indicators such as extension objectives and teaching methods. A match exits on indicators of extension principles as well as teaching aids and tools. The article suggests that to promote sustainable agricultural development, agricultural extension should be critically considered with the development policy of ending hunger and poverty in South Africa.
\end{abstract}

Keywords: Agricultural extension officers, Extension service, FORCE model; Perception index

\section{INTRODUCTION}

Globally, agricultural extension is a vital organ in the whole spectrum of food security; a strong vehicle in the transferring of information from research to the farmers and inputs from farmers to researchers to do effective research. Agriculture continues to take centre stage in the overall developmental discourse of Africa. Dewbre, Cervantes-Godoy and Sorescu (2011) argue that agriculture is integral to the physical and economic growth of every human being, serving as a key source of food, income and several other raw materials. Jones (2006) highlighted that agriculture is the "prime engine" that drives economic and social development. However, to make a meaningful contribution, farmers require some degree of protection and empowerment. This is especially true within the South African context with an agricultural sector that is characterised by its dualistic nature. On the one hand, South Africa has a well-developed commercial agricultural sector, while on the other hand, a predominantly small-scale, subsistence farming sector.

\footnotetext{
1 Senior lecturer, Department of Agricultural Economics, University of the Free State, P.O. Box 339, Bloemfontein 9300, South Africa. Email: Cloetepc@ufs.ac.za

2 Senior Researcher, Department of Agricultural Economics, University of the Free State, P.O. Box 339, Bloemfontein 9300, South Africa. Email: Bahtay@ufs.ac.za

3 Postgraduate student, University of the Free State, Development Studies Programme at the Centre for Development Support. Email: modina.m@gmail.com

${ }^{4}$ Lecturer, Department of Agricultural Economics, University of the Free State, P.O. Box 339, Bloemfontein 9300, South Africa, Email: LombardWA@ufs.ac.za
} 
S. Afr. J. Agric. Ext.

Vol. 47 No. 3, 2019: 14 - 31

http://dx.doi.org/10.17159/2413-3221/2019/v47n3a512
Cloete, Bahta,

Marunga \& Lombard

(License: CC BY 4.0)

Empowerment of small-scale farmers is carried out through the extension systems in South Africa and is primarily based on the public extension model. A significant number of people in the country are living in absolute poverty and are faced with severe food shortages (Hall \& Aliber, 2010). Although agriculture development has been prioritised by the government as one of the sectors that has the potential to make a meaningful contribution towards the fight against unemployment, poverty and subsequently food security, no meaningful contribution has been reported to date especially in small-scale and subsistence farming (Mudhara, 2010). This is mainly due to the high failure rate of agricultural development initiatives such as land reform over the past decade. Agricultural development is hampered by several challenges, foremost of which include agricultural extension services. The success of the public extension system in South Africa is questionable at best and challenges (inability to become truly responsive to local conditions and concerns, individual capacity-building and the engaging of indigenous knowledge) remain the same (Knickel et al, 2009; Simpson \& Owens, 2002; Terblanché, 2013). It is important to take note of these challenges, especially considering the view of Mutimba and Khaila (2011) that on the more subsistence-based side of the South African agricultural sector, the role of extension is basically to ensure that the farmers have appropriate knowledge and skills, hence the need to maintain engagement with those farmers, ensuring that they keep abreast of current agricultural knowledge and skills.

In a similar context, Knickel et al (2009) argued that a gap exists between the need for change and farmers' willingness to adjust, and the insufficient capacity of innovation agencies and advisory services to effectively support change. This relates closely to the poor recognition, as well as the deterioration and degradation of extension service, and subsequently the appreciation it receives from farmers. Mutimba (2014) took this a step further, stating that extension is grossly misunderstood, evident in the way in which extension is defined, the training provided to extension professionals, the way in which extension organisations are structured, and the extension approaches that are used. The approaches are top-down approaches, bottom-up participatory approaches, adopting gender-sensitive approaches, assisting farmers to form groups, linking farmers to markets - it is all aimed at achieving increased farmers' knowledge and skills. Usually, changes are made in extension systems and approaches and extensionists are expected to implement the changes without a full understanding of what it is that was wrong with the previous system that the new system is meant to address. The changes are not preceded by a thorough evaluation of the existing approaches, which means that they are not evidence-based.

The success of extension work, as a human development process for farmers, depends largely on clear objectives, principles, teaching methods, and teaching tools (Trail, 1985). These aspects, according to the Department of Agriculture, Forestry and Fisheries (DAFF, 2013), need the guidance of an explicit and comprehensive agricultural policy which is based on the primary actors, namely Agricultural Extension Officers (AEOs) and the farmers. According to Terblanché (2013), a major challenge for AEOs is the ability to understand their role and involvement when it comes to agricultural development projects. This raised the question: are the expectations of AEOs aligned with the understanding of farmers in terms of the role that they should fulfil?

Several authors have studied identifying markers for rewriting agricultural extension curricula, perceptions of agricultural extension on certain tasks of their professionals, perceptions of farmers and extension professionals on cost sharing of agricultural technology, students' perceptions of agricultural education, and the impact of advice given by extension agents to 
S. Afr. J. Agric. Ext.

Vol. 47 No. 3, 2019: 14 - 31

http://dx.doi.org/10.17159/2413-3221/2019/v47n3a512
Cloete, Bahta,

Marunga \& Lombard

(License: CC BY 4.0)

farmers, as perceived by the farmers (Androulidakis \& Siardos, 1994; Hamilton \& Hudson, 2017; Kidane \& Worth, 2014; Ozor et al, 2007; Worth, 2007). These studies do not, however, assess how different role players conceptualise extension service, especially farmers and agricultural extension officers in respect to the objective of extension service, agricultural extension principles, extension teaching methods, and teaching aids and tools. This study attempts to fill this gap in knowledge and literature. The objective of this study was to determine the perception and understanding of different dimensions of agricultural extension by farmers and extension agents in South Africa. Therefore, a major contribution of the study was to help both the AEOs and the farmers perceive extension in the same manner, and this will enhance coordination, accountability, motivation, trust, and all other aspects that will contribute towards progression of the agricultural sector. Results of the study could be very useful to the provincial and national Department of Agriculture and all other stakeholder groups on how to make the process of extension in South Africa more effective.

\section{OVERVIEW OF THE CURRENT EXTENSION MODEL IN SOUTH AFRICA}

Agricultural Extension is a fundamental tool in the agricultural sector as it facilitates knowledge transfer and enhances yields from agricultural activities. Improving smallholder farmers' access to agricultural services, especially in sub-Saharan Africa, is a central challenge facing governments in the region and yet food insecurity is greatly impeding development. Research has established that higher agricultural productivity is a precondition for growth and development in most African countries and increasing yields is key to raising incomes and reducing poverty, especially in rural areas, either directly through enhanced smallholder incomes or indirectly through increased employment and wages. In this regard, Kim, Larsen and Theus (2009) noted that on recognition of this reality, in 2002, African governments adopted a Comprehensive Africa Agriculture Development Programme (CAADP) under the support of their New Partnership for African Development (NEPAD), a programme which states that larger investments in agricultural research, extension, and education systems are required to achieve the targeted increase in agricultural output which was pegged at $6 \%$ by the year 2015.

The democratisation of South Africa has since introduced fundamental changes in the redistribution policy, administrative and delivery mechanisms, and systems for government services such as the agricultural sector, leading to the development of the White Paper on Agriculture (Department of Agriculture, 1995) to conform to the new Constitution. This saw the birth of the Broadening Access to Agriculture Thrust (BATAT) whose focus includes designing and establishing mechanisms for broadening access to agriculture for previously underserved farmers in terms of their needs for financial services, human resource development, technology development, delivery systems, and marketing services. Through the BATAT institution, the need to reorient was found to be an underlying issue since it was realised that extension as the delivery system is key to agricultural transformation and that farmers need appropriate advice efficiently and regularly.

Whilst agricultural extension has significantly contributed to large-scale farmers such as those in the fruit farming, Abdu-Raheem (2014) notes that the ineffectiveness of the extension service in meeting the current challenges, particularly among resource-challenged smallholder farmers, is widely acknowledged in South Africa. The constitution of South Africa expresses that while the National Department of Agriculture determines the policies and funding, the provision of extension is a provincial competency following the extension model (Figure 1). 
S. Afr. J. Agric. Ext.

Vol. 47 No. 3, 2019: 14 - 31

http://dx.doi.org/10.17159/2413-3221/2019/v47n3a512
Cloete, Bahta, Marunga \& Lombard (License: CC BY 4.0)

According to Abdu-Raheem (2014), the model shows that for poor households and farmers (who are the focus of state interventions in food security), extension and biodiversity conservation target the three main goals of their livelihood activities, namely income, food and social status. The focus of this study is agricultural extension, hence only agricultural extension will be explained as an intervening actor, assisting farmers to combine and sustainably harness their capitals (financial, human, natural, social and physical) and also to achieve their goals.

The current extension model has some attributes that can act as stimuli to negative perceptions towards extension by farmers. The model ultimately accedes that extension should not only focus on the outcomes (food security and biodiversity conservation), but also put energy in making it possible to bring change within the actors (farmers, rural families and extension service providers) in terms of skills, knowledge, attitudes, and behaviour. Building such a capacity will ultimately lead to the realisation of the desired outcomes and derive positive perceptions regarding the extension service. Coordination and collaboration between the principal stakeholders are essential to provide a high-quality extension service. Concurring, Abdu-Raheem (2014) is of the opinion that agricultural extension should be scaled-up in terms of lack of resources which is currently hampering its effectiveness. Furthermore, to be more influential, extension work needs to adopt a capacity-building approach with farmers and rural families, replace, or at least augment, the current single-mode, top-down technology transfer method.

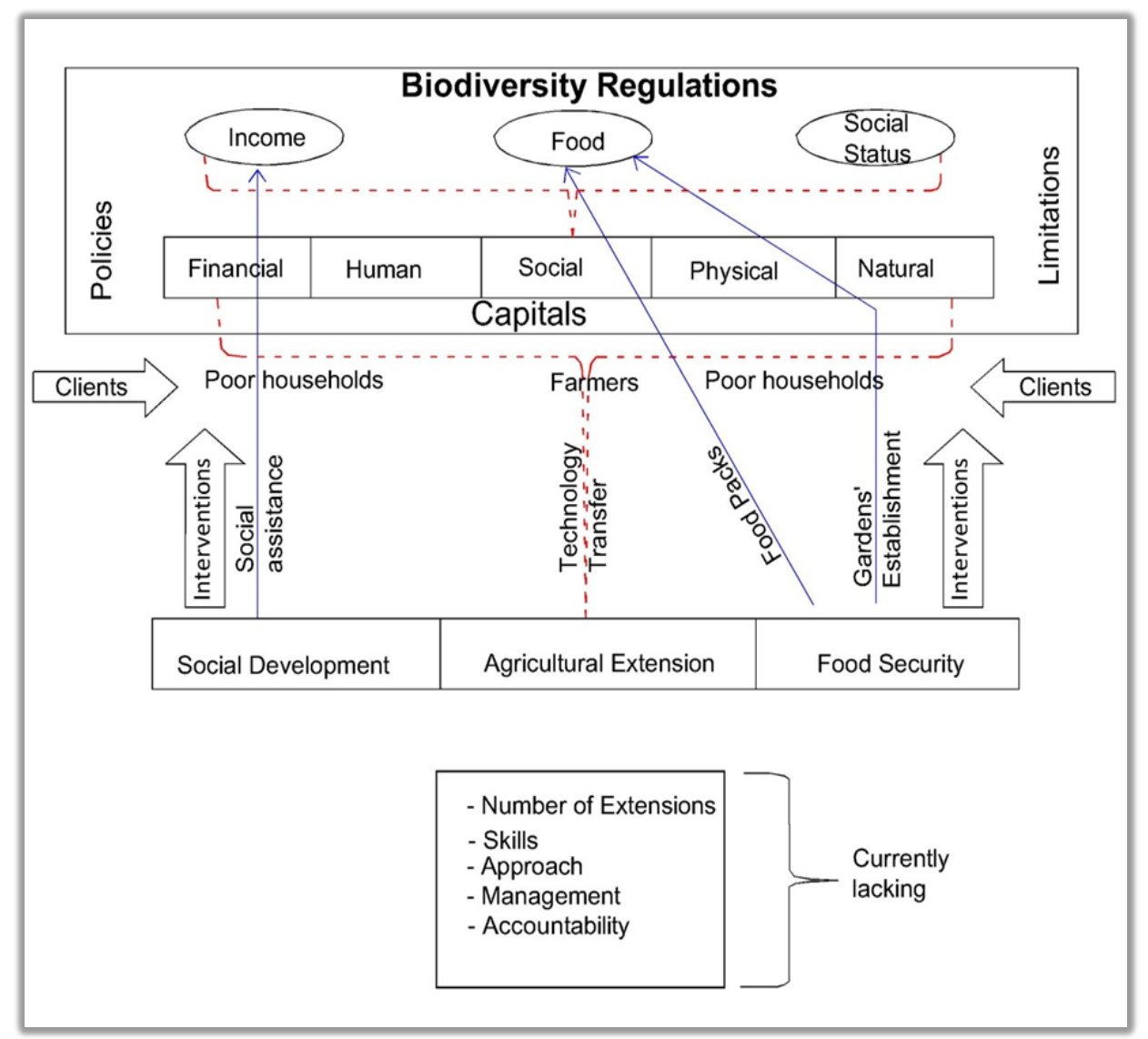

Figure 1: Current South African extension model

Note: Number of extensions - Number of extension agents.

Source: Abdu-Raheem (2014). 
S. Afr. J. Agric. Ext.

Vol. 47 No. 3, 2019: 14 - 31

http://dx.doi.org/10.17159/2413-3221/2019/v47n3a512
Cloete, Bahta,

Marunga \& Lombard

(License: CC BY 4.0)

As a result, the Department of Agriculture launched an Extension Recovery Programme (ERP) in 2011 with the aim to improve the quality of extension services throughout South Africa. Among other things, the department aimed to ensure visibility and accountability of extension, recruit more extension personnel so as to scale-up the number of front-line AEOs in ratios of 1:400 extension agents to small-scale crop farmers, 1:500 extension agents to small-scale livestock farmers, and 1:500 extension agents to small-scale mixed farm farmers. The ERP also aims to re-skill and reorient extension workers, provide Information Communication Technology (ICT) infrastructure and other resources (Abdu-Raheem, 2014). To a great extent, ERP's motives will make a big stride in livening extension work if well implemented (DAFF, 2011).

\section{METHODOLOGY}

\subsection{Study area}

The study focuses on the Thaba'Nchu area in Motheo district in the Free State Province, which is a small community east of the city of Bloemfontein. The majority of the people in the Thaba'Nchu area are poverty stricken and have an average Gross Domestic Expenditure (GDE) of R278 per household per month (less than US\$25 per month) (Mangaung Metropolitan Municipality, 2018). The main economic activity in this region revolves around agriculture, with a large percentage of the inhabitants being dependent on agriculture for their livelihoods. Climatic conditions, similar to various other municipalities in South Africa, are not highly favourable from an agricultural production perspective. On average, the Motheo District Municipality receives less than $550 \mathrm{~mm}$ of rain per annum. In addition to precipitation levels being modest, rainfall patterns tend to be erratic as well. As a result, agricultural activities mostly revolve around the rearing of livestock, with cultivation largely limited to subsistence farming practices. To improve agricultural production, a proper agricultural extension service is imperative for the district municipalities. Farmers need the assistance and added knowledge to enable them to improve their practices and know-how, and to adopt new technologies to ensure that they can sustain their livelihoods, hence, Thaba'Nchu area was found suitable for the study of farmer and AEO perceptions regarding extension services.

\subsection{The model used in the study}

The model adopted was based on the FORCE model developed by Schrader (2010), who used the model to evaluate farmer organisations' perceptions about entrepreneurial capacity. The tool was found suitable for this study given that, although the focus differs from that of Schrader (2010), the application is similar in that the focus of this study is on determining whether farmers and extension officers have different views of what extension entails or should entail. This is within the narrative that for the extension service to be successful, all participants and/or role players must have a similar view (understanding) of the scope and objective of extension services.

The FORCE model was used for the research design and questionnaire development in this study. The tool was found suitable for the study as it aims to translate the farmers' agents (extension work) into operational practices. In addition, the tool has been found to be effective as it is flexible, cost-effective and action-oriented; capable of harnessing how members can evaluate their competency and perceive extension work; able to induce a change process that can lead to capacity building and improve farming yields; capable of establishing discussion 
S. Afr. J. Agric. Ext.

Vol. 47 No. 3, 2019: 14 - 31

http://dx.doi.org/10.17159/2413-3221/2019/v47n3a512
Cloete, Bahta,

Marunga \& Lombard

(License: CC BY 4.0)

within the farming community; in a position to help the study to provide extension reports and comparative reports; and capable of providing an analytical perspective for these two key players in farming which will provide reports and recommendations in the way of conducting extension.

The basic steps of the FORCE model are as follows: customisation, formulation of statements, enabling of self-assessment to farmers, smallholder farmers scoring the statements, data capturing and processing, discussion, and recommendation. The FORCE model, therefore, enhances a quick map in terms of the perceptions surrounding the scope and/ or objective of extension as viewed by farmers and agricultural extension officers (AEOs) respectively. For a more detailed account of the methodology refer to Schrader (2010).

A total of 95 farmers and five agricultural extension officers scored the statements, using a 5point Likert scale. Farmers provided a score according to their level of agreement or disagreement on the asymmetric agree-disagree scale (0-5) for each statement. The score indicates their feeling or opinion in a statement. For each statement, they were asked two important questions: "Do they agree or not agree with the specified statements (question)?" and "to what extent it is agreeable or not?" In this regard, the level of agreement with the statement (score towards 5) or disagreement (score towards 0) with the question (statement) was approximately measured.

Perception index was also used as an indicator of the farmers' perceptions on the objectives of extension service, agricultural extension principles, extension instruction methods, teaching aids, tools and challenges of extension service work. Areas of self-assessment and elements covered during interviews are depicted in Tables 3 to 6 with a perception index result.

\subsection{Sampling procedure}

The study used primary data that was collected by means of a questionnaire from 95 smallholder farmers and five agricultural extension officers (AEOs). Following the FORCE model, the questionnaire was divided into four sections, namely (i) objective of extension service, (ii) agricultural extension principles, (iii) extension instruction methods, teaching aids, and tools, and (iv) challenges of extension service work. The target population comprised all the crop and livestock smallholder farmers in the Thaba'Nchu area. A workshop was conducted as a platform to administer questionnaires and to discuss with the target group. After the workshops, face-to-face interviews were conducted at smallholder farmers' homesteads by the authors in collaboration with the extension officers in the district. The data were collected in 2015. Verbal consent was sought from respondents to fill in the questionnaire. Farmers who could not read or write were assisted to complete the questionnaire. Translation from English to Sotho (local language of the Free State Province) and vice versa was provided. The smallholder farmers sampled were those who were willing to participate in the survey, after the purpose of the study was explained to them in a workshop with five AEOs. The participants were conveniently selected from five (Kgalala and Paradays; Mfubofu; Modutond, Longrich and Mariasdale villages (farming wards)) of the nine farming wards in the study district municipalities (Motheo). The total sample size consisted of 95 farmers (on average 19 from each ward) and five AEOs from Thaba'Nchu local Department of Agriculture. The sample size in terms of the AEOs is representative of the total population, in other workds, the total number of AEOs active in the particular district municipalities. 
S. Afr. J. Agric. Ext.

Vol. 47 No. 3, 2019: 14 - 31

http://dx.doi.org/10.17159/2413-3221/2019/v47n3a512
Cloete, Bahta,

Marunga \& Lombard

(License: CC BY 4.0)

\subsection{Data analysis}

Following data collection, the individual members' responses were placed into the FORCE model in Excel. The data was analysed in such a way as to obtain a median score for each of the factors within the different themes. This formed the basis for comparing how and if perceptions between farmers and AEOs differ as far as the scope of extension services is concerned. Moreover, the survey data collected from the sampled respondents were processed and used in estimating a perception index score. Prior to the FORCE model analysis and the estimation of the perception index score, summary statistics of the smallholder farmers were described to give an overview of the socio-economic characteristics of the respondents. Among the socio-economic characteristics, age, gender, educational status, and farming experience were analysed.

Apart from the survey and FORCE model in this study, a perception index score was used. A perception index score is a composite index that ranks indicators based on how respondents perceive extension. Farmers' perceptions of extension service have a binary nature of the response and a respondent's choice lies on "agree" and "disagree" with numbers of respondents and the agreed respondent assigned a positive value $(+1)$ and the disagreed respondent assigned a negative value $(-1)$. For estimation of perception index for each statement, categories were based on questions: "Do they agree or not agree with the specified statements (question)?" Responses were categorised as $0=$ absolutely disagree; $1=$ strongly disagree; $2=$ disagree; 3 $=$ agree $;=$ strongly agree; and $5=$ absolutely agree $($ Table 1$)$.

Table 1: Categorisation of agree and disagree with two statements

\begin{tabular}{lcc|cccc}
\cline { 5 - 6 } & Disagree & & \multicolumn{3}{c}{ Agree } \\
\hline Score & 1 & 2 & 3 & 4 & 5 \\
0 & 1 & 2 & 3 & 4 & 5 \\
0 & & & & & & \\
\hline
\end{tabular}

The mean score value is used as the perception index score and is expressed as: Mean score $=\sum \frac{\text { No.of Agreed respondent }- \text { No. Disagree respondent }}{\text { Total number of respondent }}$

The closer the mean score is to -1 , the greater the negative perception is, and vice versa.

\section{RESULTS AND DISCUSSION}

\subsection{Socio-economic characteristics of the respondents}

It was anticipated that farmers and AEOs with different demographical characteristics could have different perceptions regarding extension services. This was based on different narratives, for example, someone with a tertiary education might have a completely different view of extension when compared to someone with no formal education, or someone whose livelihood depends solely on his/ her farming activities, compared to someone who is making a living from both farming and other farming related or non-farming related activities. The demographic and socio-economic characteristics are important since they influence households' economic behaviour (Randela, 2005). Table 2 illustrates the socio-economic characteristics of respondents. 
S. Afr. J. Agric. Ext.

Vol. 47 No. 3, 2019: 14 - 31

http://dx.doi.org/10.17159/2413-3221/2019/v47n3a512
Cloete, Bahta,

Marunga \& Lombard (License: CC BY 4.0)

The farmers' age groups of 30-40 and 50+ years had a lion share compared to other age categories. This implies that the higher age groups tend towards disagreement with the statement, especially related to technology. Instead, some of the elderly farmers stated that extension should concentrate on supplying them with inputs. Such an ideology could have been motivated by the fact that one of the extension model intervention strategies, as presented by Abdu-Raheem (2014), is to give handouts where necessary. Hence, this could have created a misconception regarding the overall aim of extension service to the farmers, who generally identify the objectives of extension as revolving around sourcing inputs for the communal people and not focusing on helping them to realise their capabilities.

Furthermore, 38\% of respondents had farming experience of 5-9 years, although experience is gained with age, farming needs not be dominated by aged populations in any region, as this could have negative implications on future food production (Carino, 2013).

Table 2: Socio economic characteristics of the respondents

\begin{tabular}{|c|c|c|c|}
\hline Farmer characteristics & Sub-characteristics & Frequency & $\%$ \\
\hline \multirow[t]{2}{*}{ Gender } & Male & 63 & 66 \\
\hline & Female & 32 & 34 \\
\hline \multirow[t]{4}{*}{ Age } & $<30$ & 25 & 26 \\
\hline & $30-40$ & 27 & 28 \\
\hline & $40-50$ & 17 & 18 \\
\hline & $>50$ & 26 & 27 \\
\hline \multirow[t]{6}{*}{ Education } & No schooling & 5 & 5 \\
\hline & Primary & 27 & 28 \\
\hline & Secondary & 50 & 53 \\
\hline & $\begin{array}{l}\text { Tertiary: degree or diploma in } \\
\text { agricultural related field }\end{array}$ & 4 & 4 \\
\hline & $\begin{array}{l}\text { Tertiary: degree or diploma in } \\
\text { commerce field }\end{array}$ & 2 & 2 \\
\hline & $\begin{array}{l}\text { Tertiary: degree or diploma in other } \\
\text { field }\end{array}$ & 7 & 7 \\
\hline \multirow[t]{4}{*}{ Farming experience } & $<1$ & 3 & 3 \\
\hline & $1-4$ & 23 & 24 \\
\hline & $5-9$ & 36 & 38 \\
\hline & $>10$ & 33 & 35 \\
\hline \multirow[t]{3}{*}{ Ownership of land } & Owned & 13 & 14 \\
\hline & Leased & 79 & 83 \\
\hline & Communal & 3 & 3 \\
\hline \multirow[t]{2}{*}{ Any form of cooperative } & Yes & 63 & 66 \\
\hline & No & 32 & 34 \\
\hline \multirow[t]{3}{*}{ Extent of assistance by cooperative } & Input sourcing & 59 & 94 \\
\hline & Decision making & 3 & 5 \\
\hline & Marketing & 1 & 2 \\
\hline AEOs characteristics & Sub-characteristics & Frequency & $\%$ \\
\hline \multirow[t]{2}{*}{ Gender } & Male & 3 & 60 \\
\hline & Female & 2 & 40 \\
\hline
\end{tabular}


S. Afr. J. Agric. Ext.

Vol. 47 No. 3, 2019: 14 - 31

http://dx.doi.org/10.17159/2413-3221/2019/v47n3a512
Cloete, Bahta,

Marunga \& Lombard

(License: CC BY 4.0)

\begin{tabular}{|l|l|l|l|}
\hline Education & Tertiary: degree or diploma & 5 & 100 \\
\hline Experience in extension service & $1-4$ & 1 & 20 \\
\hline & $5-9$ & 3 & 60 \\
\hline & $>10$ & 1 & 20 \\
\hline $\begin{array}{l}\text { Among group or individual farmers } \\
\text { is difficult to make decision }\end{array}$ & Group & 5 & 100 \\
\hline & Individual & 0 & 0 \\
\hline
\end{tabular}

For the sample of farmers, 5\% did not have any schooling at all, $28 \%$ of the respondents attended primary school, 53\% of the respondents attended high school, 4\% have diplomas/ degrees related to agriculture, $2 \%$ have diplomas/ degrees related to commerce, and $7 \%$ have diplomas/ degrees related to other fields. Education is very important in developing a community. The lack of education is associated with marginalisation and poverty, and less educated farmers have a greater probability of lagging behind in terms of gaining access to information and technology (Bahta, Jordaan \& Muyambo, 2016). Afzal, Al-Subaiee and Mirza (2016) emphasised that to get the necessary information, scientific education and some sort of scientific approach is required, the absence of which may act as a hindrance to farmers with no formal education.

\subsection{The perception of smallholder farmers and AEOs towards extension objectives}

Faure, Desjeux and Gasselin (2012) highlighted that agricultural extension services are perceived by many actors involved in rural development as important elements not only in improving farm performance, but also in strengthening ties between farmers, research, agricultural education and other actors of the society.

The objective is the main determinants of extension services. The objectives are adopted from the Department of Agriculture's job scope for extension and international specifications for agricultural extension roles. Table 3 provides an overview of how perceptions in terms of the main objectives of extension services differ between farmers and agricultural extension officers (AEOs). It is clear from Table 3 that the views of farmers and extension officers differ when it comes to the objectives of extension services. Moreover, the results suggest that even AEOs are unsure when it comes to the objectives of extension services. This could be one of the main reasons for why extension services are not achieving the desired outcomes. Table 3 shows that from a farmer's perspective, encouraging farmers to farm for family consumption only had a lion share $(40 \%)$ compared to other indicators.

Smallholder farmers and extension officers had a different perception on the objectives of extension. A perception index of -0.40 for farmers and 0.76 for extension officers is observed (Table 3). Farmers who have a low perception with regards to the objective of extension officers indicated that they do not produce the necessary production due to insufficient knowhow of research, lack of proper farming, lack of marketing, and lack of cooperatives.

The respondents (farmers) perceived the role of extension service objective very low $(30.18 \%)$ (Table 3). The extension officers shared different sentiments on the objective of extension service $(87.78 \%)$. The limited knowledge of farmers contributes towards the farmers' vulnerability. The lack of helping farmers locate the farm-inputs source $(22.11 \%$ - the lowest $)$ reduces the farmers' capacity to produce. 
S. Afr. J. Agric. Ext.

Vol. 47 No. 3, 2019: 14 - 31

http://dx.doi.org/10.17159/2413-3221/2019/v47n3a512
Cloete, Bahta,

Marunga \& Lombard

(License: CC BY 4.0)

Table 3: Farmers' and AEOs' perceptions in terms of objectives of extension service

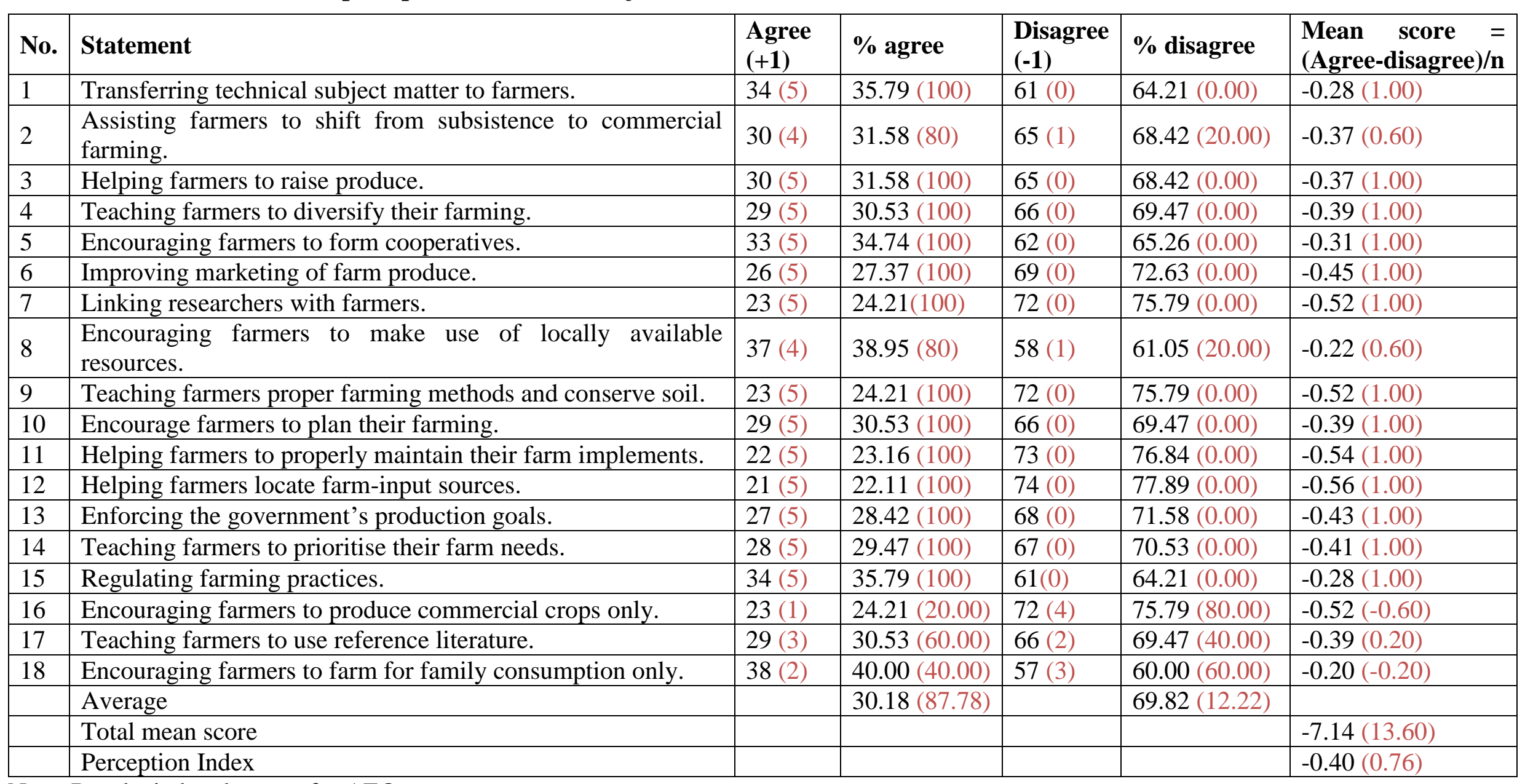

Note: Results in brackets are for AEOs. 


\subsection{The perception of smallholder farmers and AEOs towards extension principles}

In this study, respondents were assessed in terms of their perceptions of extension principles as detailed by Vanclay (2004). It was observed that, to a large extent, there is a convergence of perceptions with regards to extension principles. The majority of both farmers $(64.21 \%)$ and all the AEOs (100\%) shared the view that extension meetings should be made compulsory, provided that they promote the participation of farmers, which would go a long way in terms of promoting cohesiveness (Table 4). Another issue of convergence is the principle of using opinion leaders in extension work, with $63.16 \%$ of farmers and just over $60 \%$ of AEOs expressing the view that opinion leaders could aid in more effective and credible information dissemination (Table 4). The same applies to principles such as the use of formative and summative evaluation methods.

Mismatches are, however, unavoidable, as is evident in terms of the perception concerning the use of the grassroots approach and the reliance on applied research. A grassroots approach seeks solutions at the root of the problem and develops them to applicable parties by involving them in both the goal-setting and implementation stages. In this approach, the farmers need to be involved as much as possible, because they are the immediate recipients of the extension services. However, only $40 \%$ of the farmers believe in the application of grassroots-based approaches in implementing extension programmes compared to a staggering $80 \%$ of AEOs who agreed that grassroots should be used (Table 4). This means that there is likely to be resistance on the part of the farmers in terms of embracing a grassroots-based approach, potentially leading to significant frustration on the part of extension workers, because even having a tertiary education seems to have had no impact on farmers' perceptions regarding grassroots-based approaches. However, only $42.11 \%$ of the farmers believe in applied research compared to $100 \%$ of AEOs who think otherwise (Table 4). This implies that it is necessary to enhance farmers' education on the advantages of using the results of applied research in extension.

Farmers with a strong know-how of extension principles cope better than those without any. As shown in Table 4, the perception index for extension principle is 0.19 for farmers and 0.76 for AEOs. Both farmers and AEOs consider extension principles as being necessary to achieve the desired result. Farmers hold negative perceptions $(-0.20)$ and $(-0.16)$ in relation to the extension, in order improve the perception towards extension, extension officers should use a grassroots approach and applied research to solve farmers' problems and enhance their role.

Gurstein (2013) recommended that providing additional Information and Communications Technologies, research, supports and training for intermediary groups to facilitate their work in enabling policy inputs from and to the grassroots is of primary importance. Similarly, with sharing of Agriculture and Rural Development knowledge are crucial foundations for grassroots inputs to policy-making.

Table 4 indicates that $71.58 \%$ of the farmers and $100 \%$ of AEOs acknowledged that farmers should develop problem-solving skills compared with other indicators. From the average score result, it is deduced that the extension principle is generally moderately involved with $59.58 \%$ of farmers and $88 \%$ of AEOs. 
S. Afr. J. Agric. Ext.

Vol. 47 No. 3, 2019: 14 - 31

http://dx.doi.org/10.17159/2413-3221/2019/v47n3a512
Cloete, Bahta,

Marunga \& Lombard

(License: CC BY 4.0)

Table 4: Farmers' and AEOs' perceptions in terms of agricultural extension principles

\begin{tabular}{|c|c|c|c|c|c|c|}
\hline No. & Statement & $\begin{array}{l}\text { Agree } \\
(+1)\end{array}$ & $\%$ agree & $\begin{array}{l}\text { Disagree } \\
(-1)\end{array}$ & \% disagree & $\begin{array}{l}\text { Mean } \quad \text { score } \\
=(\text { Agree-disagree }) / \mathbf{n}\end{array}$ \\
\hline 2 & $\begin{array}{l}\text { Extension should use a grassroots approach to farmers' } \\
\text { problems. }\end{array}$ & $38(4)$ & $40.00(80.00)$ & $57(1)$ & $60.00(20.00)$ & $-0.20(0.60)$ \\
\hline 3 & $\begin{array}{l}\text { Extension should provide services to farmers on non- } \\
\text { discriminatory basis. }\end{array}$ & $49(5)$ & $51.58(100.00)$ & $46(0)$ & $48.42(0.00)$ & $0.03(1.00)$ \\
\hline 4 & Extension should put reliance on applied research. & $40(5)$ & $42.11(100.00)$ & $55(0)$ & $57.89(0.00)$ & $-0.16(1.00)$ \\
\hline 7 & $\begin{array}{l}\text { Extension should promote consultation/ networking among } \\
\text { farmers. }\end{array}$ & $62(4)$ & $65.26(80.00)$ & $33(1)$ & $34.74(20.00)$ & $0.31(0.60)$ \\
\hline 8 & $\begin{array}{l}\text { Other agencies should cooperate with extension staff and } \\
\text { vice-versa. }\end{array}$ & $56(5)$ & $58.95(100.00)$ & $39(0)$ & $41.05(0.00)$ & $0.18(1.00)$ \\
\hline 9 & Extension should lead farmers toward self-reliance. & $60(5)$ & $63.16(100.00)$ & $35(0)$ & $36.84(0.00)$ & $0.26(1.00)$ \\
\hline 10 & Farmers should develop problem-solving skills. & $68(5)$ & $71.58(100.00)$ & $27(0)$ & $28.42(0.00)$ & $0.43(1.00)$ \\
\hline 14 & $\begin{array}{l}\text { Farmers' participation in extension meetings should be } \\
\text { compulsory. }\end{array}$ & $61(3)$ & $64.21(60.00)$ & $34(2)$ & $35.79(40.00)$ & $0.28(0.20)$ \\
\hline \multirow[t]{4}{*}{15} & $\begin{array}{l}\text { New programmes should be presented using suitable } \\
\text { extension teaching method(s). }\end{array}$ & $61(5)$ & $64.21(100.00)$ & $34(0)$ & $35.79(0.00)$ & $0.28(1.00)$ \\
\hline & Average & & $59.58(88.00)$ & & $40.42(12)$ & \\
\hline & Total mean score & & & & & $2.87(11.40)$ \\
\hline & Perception Index & & & & & $0.19(0.76)$ \\
\hline
\end{tabular}


S. Afr. J. Agric. Ext.

Vol. 47 No. 3, 2019: 14 - 30

http://dx.doi.org/10.17159/2413-3221/2019/v47n3a512
Cloete, Bahta,

Marunga \& Lombard

(License: CC BY 4.0)

\subsection{The perception of smallholder farmers and AEOs towards teaching methods}

Teaching methods are fundamental tools for knowledge transfer. However, care must be taken in choosing a method that is suitable for effective content delivery. Mismatches between the perceptions of farmers and AEOs are established (Table 5). While AEOs expressed satisfaction with quite a number of methods at their disposal, many farmers do not believe in the effectiveness thereof. For example, all AEOs indicated that methods such as demonstrations, individual farm visits, short courses, field days, workshops, case studies, on-farm trails, and general discussions are amongst the most effective ways of transferring knowledge. Table 5 indicates that $58.95 \%$ of the farmers acknowledged the discussion is the main teaching method followed by short courses (53.68\%) and individual farm visits accounted for 50.53\% respectively. From the average score result, it is deduced that teaching methods were considered as important tools in the extension teaching by below $50 \%$ of farmers. Only $43.95 \%$ of farmers perceive that teaching method is important, ranging from tours $(30.53 \%)$ to result in a demonstration (49.97\%). It is interesting to note that farmers' perceptions in terms of the effectiveness of teaching methods differ significantly, with few specific methods being singled out by the majority as an effective way of transferring knowledge. This implies that most of the farmers perceived that extension services are not effective or efficient.

Table 5: Farmers' and AEOs' perceptions towards extension teaching methods

\begin{tabular}{|l|l|l|l|l|l|l|}
\hline No. & Statement & $\begin{array}{l}\text { Agree } \\
(+1)\end{array}$ & \% agree & $\begin{array}{l}\text { Disagree } \\
\mathbf{( - 1 )}\end{array}$ & \% disagree & $\begin{array}{l}\text { Mean score } \\
\text { (Agree- } \\
\text { disagree)/n }\end{array}$ \\
\hline 1 & $\begin{array}{l}\text { Individual farmer visits } \\
\text { (individualised } \\
\text { instruction) }\end{array}$ & $48(5)$ & $50.53(100.00)$ & $47(0)$ & $49.47(0.00)$ & $0.01(1.00)$ \\
\hline 2 & Agricultural shows & $30(4)$ & $31.58(80.00)$ & $65(1)$ & $68.42(20.00)$ & $-0.37(0.60)$ \\
\hline 3 & Method demonstrations & $50(5)$ & $52.63(100.00)$ & $45(0)$ & $47.37(0.00)$ & $0.05(1.00)$ \\
\hline 4 & Result demonstrations & $47(5)$ & $49.47(100.00)$ & $48(0)$ & $50.53(0.00)$ & $-0.01(1.00)$ \\
\hline 5 & Short courses & $51(5)$ & $53.68(100.00)$ & $44(0)$ & $46.32(0.00)$ & $0.07(1.00)$ \\
\hline 6 & Field days & $31(5)$ & $32.63(100.00)$ & $64(0)$ & $67.37(0.00)$ & $-0.35(1.00)$ \\
\hline 7 & Workshops & $46(5)$ & $48.42(100.00)$ & $49(0)$ & $51.58(0.00)$ & $-0.03(1.00)$ \\
\hline 8 & Discussions & $56(5)$ & $58.95(100.00)$ & $39(0)$ & $41.05(0.00)$ & $0.18(1.00)$ \\
\hline 9 & Case studies & $34(5)$ & $35.79(100.00)$ & $61(0)$ & $64.21(0.00)$ & $-0.28(1.00)$ \\
\hline 10 & $\begin{array}{l}\text { Problem-solving } \\
\text { (decision-making) }\end{array}$ & $46(5)$ & $48.42(100.00)$ & $49(0)$ & $51.58(0.00)$ & $-0.03(1.00)$ \\
\hline 11 & On-farm trials & $33(5)$ & $34.74(100.00)$ & $62(0)$ & $65.26(0.00)$ & $-0.31(1.00)$ \\
\hline 12 & Tours & $29(4)$ & $30.53(80.00)$ & $66(1)$ & $69.47(20.00)$ & $-0.39(0.60)$ \\
\hline & Average & & $43.95(96.67)$ & & $56.05(3.33)$ & \\
\hline & Total mean score & & & & & $-1.45(11.20)$ \\
\hline & Perception Index & & & & & $-0.12(0.93)$ \\
\hline
\end{tabular}

As indicated in Table 5, the perception index for teaching methods for farmers is -0.12 and AEOs is 0.93. Contrary to the AEOs, farmers did not consider teaching methods as being effective. Farmers hold the strongest negative perception on tours (-0.39) in relation to teaching methods. Shanthy and Thiagarajan (2011) express that extension involves the conscious use of communication to help people form sound opinions and make good decisions. Therefore, the 
S. Afr. J. Agric. Ext.

Vol. 47 No. 3, 2019: 14 - 31

http://dx.doi.org/10.17159/2413-3221/2019/v47n3a512
Cloete, Bahta,

Marunga \& Lombard

(License: CC BY 4.0)

level of farmers' participation will impact the success of any sustainable local development programmes, through proper use of extension teaching methods.

\subsection{The perception of smallholder farmers and AEOs towards teaching aids and tools}

Teaching aids and tools are an integral part of teaching methods. Interesting to note is that the views of farmers and AEOs do not differ significantly in terms of the effectiveness of different teaching aids and tools (Table 6). There is clearly a convergence of opinions regarding the use of electronic mass communication media such as radio and television in carrying out extension teaching. This is somewhat unexpected, given the vast differences in perceptions in terms of teaching methods. The largest difference in perceptions pertains to tours, with $40 \%$ of the farmer respondents indicating that tours and internet/ email aided instruction are an effective teaching aid, compared to the almost $20 \%$ of AEOs for internet/ email aided instruction and $80 \%$ of AEOs for tours (Table 6). Furthermore, $60 \%$ of AEOs and $57.89 \%$ of farmers indicated/ perceived that video tapes are efficient teaching aids. This finding also concurs with that of Zossou et al (2009) who found that videotapes are rich in images and are able to reach more people compared to conventional training workshops and learning by motion pictures is easier and more enjoyable than learning without motion pictures. Faure et al (2012) supported the idea that multimedia leads to positive arousal and this contributes positively to learning attitude and motivation.

Table 6 indicates that a positive perception index was observed between farmers and AEOs with 0.33 and 3.40 respectively. The real object had a lion share $(62.11 \%)$ compared to other indicators for farmers. The highest negative perception index was observed by farmers for films with -0.22 and AEO internet/ email aided instruction with -0.60 . This finding concurs with the finding of Shinn (1997) who found that real-object approaches ranked highly in the same study while the following tools and strategies, namely magnetic boards, dramatic skits, opaque projectors, flip charts, radio programmes, seminars, and learning centres were rarely used or not used at all. Faure et al (2012) highlighted that the importance of using teaching aids and tools in favouring cooperation between AEO and farmers, who should both work together to resolve farm management problems.

Table 6: Farmers' and AEOs' perceptions towards teaching aids and tools

\begin{tabular}{|l|l|l|l|l|l|l|}
\hline No. & Statement & $\begin{array}{l}\text { Agree } \\
(+\mathbf{1})\end{array}$ & \% agree & $\begin{array}{l}\text { Disagree } \\
\mathbf{( - 1 )}\end{array}$ & \% disagree & $\begin{array}{l}\text { Mean score } \\
=(\text { Agree- } \\
\text { disagree)/n }\end{array}$ \\
\hline 1 & $\begin{array}{l}\text { Field Support } \\
\text { Guides }\end{array}$ & $50(2)$ & $52.63(40.00)$ & $45(3)$ & $47.37(60.00)$ & $0.05(-0.20)$ \\
\hline 2 & Projectors & $54(4)$ & $56.84(80.00)$ & $41(1)$ & $43.16(20.00)$ & $0.14(0.60)$ \\
\hline 3 & Tours & $38(4)$ & $40.00(80.00)$ & $57(1)$ & $60.00(20.00)$ & $-0.20(0.60)$ \\
\hline 4 & Newsletter & $49(3)$ & $51.58(60.00)$ & $46(2)$ & $48.42(40.00)$ & $0.03(0.20)$ \\
\hline 5 & $\begin{array}{l}\text { Instructional } \\
\text { posters }\end{array}$ & $50(2)$ & $52.63(40.00)$ & $45(3)$ & $47.37(60.00)$ & $0.05(-0.20)$ \\
\hline 6 & Bulletin boards & $45(3)$ & $47.37(60.00)$ & $50(2)$ & $52.63(40.00)$ & $-0.05(0.20)$ \\
\hline 7 & $\begin{array}{l}\text { Internet/ email } \\
\text { aided instruction }\end{array}$ & $38(1)$ & $40.00(20.00)$ & $57(4)$ & $60.00(80.00)$ & -0.20 \\
\hline 8 & Television & $55(3)$ & $57.89(60.00)$ & $40(2)$ & $42.11(40.00)$ & $0.16(0.20)$ \\
\hline 9 & Video tapes & $55(3)$ & $57.89(60.00)$ & $40(2)$ & $42.11(40.00)$ & $0.16(0.20)$ \\
\hline
\end{tabular}


S. Afr. J. Agric. Ext.

Vol. 47 No. 3, 2019: 14 - 31

http://dx.doi.org/10.17159/2413-3221/2019/v47n3a512
Cloete, Bahta,

Marunga \& Lombard

(License: CC BY 4.0)

\begin{tabular}{|l|l|l|l|l|l|l|}
\hline 10 & Radio & $58(4)$ & $61.05(80.00)$ & $37(1)$ & $38.95(20.00)$ & $0.22(0.60)$ \\
\hline 11 & Real objects & $59(4)$ & $62.11(80.00)$ & $36(1)$ & $37.89(20.00)$ & $0.24(0.60)$ \\
\hline 12 & $\begin{array}{l}\text { Exhibits and } \\
\text { displays }\end{array}$ & $52(4)$ & $54.74(80.00)$ & $43(1)$ & $45.26(20.00)$ & $0.09(0.60)$ \\
\hline 13 & Films & $37(3)$ & $38.95(60.00)$ & $58(2)$ & $61.05(40.00)$ & $-0.22(0.20)$ \\
\hline 14 & $\begin{array}{l}\text { Agricultural } \\
\text { Research Reports }\end{array}$ & $43(3)$ & $45.26(60.00)$ & $52(2)$ & $54.74(40.00)$ & $-0.09(0.20)$ \\
\hline 15 & Advisory Bulletin & $45(3)$ & $47.37(60.00)$ & $50(2)$ & $52.63(40.00)$ & $-0.05(0.20)$ \\
\hline & Average & & $51.09(61.33)$ & & $48.91(38.67)$ & \\
\hline & Total mean score & & & & & $0.33(3.40)$ \\
\hline & Perception Index & & & & & $0.02(0.23)$ \\
\hline
\end{tabular}

\section{CONCLUSION AND RECOMMENDATIONS}

It is clear from the results that notable differences exist in terms of the perceptions of what agricultural extension entails or should entail, the principles of extension, and what is effective or not effective in terms of methods of information delivery and/ or teaching. Part of the misconception could be due to demographical factors coupled with past practices of government. Many of the farmer respondents were of the opinion that the main function of extension is to supply/ assist with inputs and not to assist with technical information and training to enable them to reach their potential. There is clearly an underlying ideology of dependence on the extension officers for inputs, and as a result, differences in perceptions. This is further aggravated by the fact that AEOs are unsure about their roles and responsibilities, in other words, the objectives of extension services. This may be a result of a system or model whereby differentiation exists in terms of knowledge, experience, capacity, and subsequently the level of employment with the Department of Technical Advisory Services, more commonly known as extension services.

The result is almost a complete mismatch in terms of the perception amongst farmers and AEOs as far as the basics of extension services are concerned. This finding holds important policy implications. If South Africa is to achieve a turnaround in agricultural performance in rural areas, and in so doing address some of the main national imperatives, it is paramount to ensure that all stakeholders share the same understanding of the basic principles of extension.

A more common understanding of extension could be achieved through the introduction of a strong awareness plan. Both AEOs and farmers need regular in-service courses and workshops to help them keep abreast with the technical developments in farming. They need to be well versed with the current technical language and skills of agriculture together with current information on climate and market development, which are amongst the major determining issues in agriculture. It is also recommended that AEOs be encouraged to be versatile in the choice of teaching methods. There is a need to use suitable and varied methods so as to stimulate interest in the farmers. Teaching methods should encourage active interactions between farmers and AEOs. It is highly recommended that farmers be familiarised with various learning tools which will accentuate information transfer. In this regard, AEOs are also encouraged to be innovative and come up with interesting sessions with a variety of teaching aids. Incentives for AEOs need to be equitable to their input. Lastly, it is also important that AEOs be stationed in a particular area for reasonably long periods of time, long enough to build relationships with the farmers and to understand their individual problems. 
S. Afr. J. Agric. Ext.

Vol. 47 No. 3, 2019: 14 - 31

http://dx.doi.org/10.17159/2413-3221/2019/v47n3a512
Cloete, Bahta,

Marunga \& Lombard

(License: CC BY 4.0)

\section{REFERENCES}

ABDU-RAHEEM, K.A., 2014. Modelling effective and simultaneous promotion of food security and biodiversity conservation through agricultural extension activities. S. Afr. J. Agric. Ext., 42(2):51-61.

AFZAL, A., AL-SUBAIEE, F.S. \& MIRZA, A.A., 2016. The attitudes of agricultural extension workers towards the use of e-extension for ensuring sustainability in the Kingdom of Saudi Arabia. Sustainability, 8(10):1-10.

ANDROULIDAKIS, S.I. \& SIARDOS, G.C., 1994. Agricultural extension agents' perceptions regarding their relevance and competence in certain professional task areas. Eur. J. Agric. Educ. Ext., 1(3):1-13.

BAHTA, Y.T., JORDAAN, A.J. \& MUYAMBO, F., 2016. Communal farmers' perception of drought in South Africa: Policy implication for drought risk reduction. Int. J. Disast. Risk Re., 20:39-50.

CARINO, C.M., 2013. The Manila Times. Aging Filipino farmers to affect food security. Available from: http://www.manilatimes.net/aging-filipino-farmers-to-affectfoodsecurity/12166/

DEPARTMENT OF AGRICULTURE, 1995. White paper on agriculture. Available from: https://www.nda.agric.za/docs/policy/whitepaper.htm

DEPARTMENT OF AGRICULTURE, FORESTRY AND FISHERIES (DAFF), 2011. National framework for extension recovery plan. Available from: https://www.nda.agric.za/doaDev/sideMenu/educationAndTraining/framework recover y\%20plan_web.pdf

DEPARTMENT OF AGRICULTURE, FORESTRY AND FISHERIES (DAFF), 2013. National Agro-meteorological Committee (NAC) advisory on the 2013 Autumn/Winter season statement from climate change and disaster management. Available from: https://www.nda.agric.za/doaDev/topMenu/doc/07Ad12\%20for\%20Mar2013.pdf

DEWBRE, J., CERVANTES-GODOY, D. \& SORESCU, S., 2011. Agricultural progress and poverty reduction. Working Paper 49. OECD, France.

FAURE, G., DESJEUX, Y.B. \& GASSELIN, P., 2012. New challenges in agricultural extension services from a research perspective: A literature review, synthesis and research agenda. J. Agric. Educ. Ext., 18(5):461-492.

GURSTEIN, M., 2013. Community innovation and community informatics. Available from: https://pdfs.semanticscholar.org/8286/a18857ef067071ba32d78647809b4c180174.pdf

HALL, R. \& ALIBER, M., 2010. The case for re-strategizing spending priorities to support small scale in South Africa. Working Paper 17. PLAAS, University of the Western Cape, South Africa.

HAMILTON, A. \& HUDSON, J., 2017. The perceived impact of agricultural advice in Ethiopia. J. Agric. Educ. Ext., 23(3):159-173.

JONES, M., 2006. Knowledge for development: Observatory on science and technology for ACP. Available from: http://knowledge.cta.int 
KIDANE, T.T. \& WORTH, S.H., 2014. Student perceptions of agricultural education programme processes at selected high schools in KwaZulu-Natal Province, South Africa. J. Agric. Educ. Ext., 20(4):381-396.

KIM, R., LARSEN, K. \& THEUS, F., 2009. Introduction and main messages. In Agribusiness and innovation systems in Africa (pp.1-14). Washington, D.C: The World Bank.

KNICKEL, K., BRUNORI, G., RAND, S. \& PROOST, J., 2009. Towards a better conceptual framework for innovation processes in agriculture and rural development: From linear models to systemic approaches. J. Agric. Educ. Ext., 15(2):131-146.

MANGAUNG METROPOLITAN MUNICIPALITY, 2018. Integrated development plan. Available from: http://www.mangaung.co.za/wp-content/uploads/2018/06/IDP-201819-FINAL-5-June-2018.pdf

MUDHARA, M., 2010. Agrarian transformation in smallholder agriculture in South Africa: A diagnosis of bottlenecks and public policy options. Paper presented to Overcoming inequality and structural poverty in South Africa: Towards inclusive growth and development. Johannesburg, South Africa.

MUTIMBA, J.K., 2014. Reflections on agricultural extension and extension policy in Africa. S. Afr. J. Agric. Ext., 42(1):15-26.

MUTIMBA, J.K. \& KHAILA, S., 2011. Action research: A practical step-by-step guide for agricultural extension professionals. S. Afr. J. Agric. Ext., 39(1):26-34.

OZOR, N., AGWU, A.E., CHUKWUONE, N.A., MADUKWE, M.C. \& GARFORTH, C.J., 2007. Cost-sharing of agricultural technology transfer in Nigeria: Perceptions of farmers and extension professionals. J. Agric. Educ. Ext., 13(1):23-37.

RANDELA, R., 2005. Integration of emerging cotton farmers into the agricultural economy. $\mathrm{PhD}$ Thesis, University of the Free State.

SCHRADER, T., 2010. Engaging with farmers as entrepreneurs and partners: Experiences with a self-assessment tool for farmers' organisations (FORCE). Available from: https://library.wur.nl/WebQuery/wurpubs/fulltext/232555

SHANTY, T.R. \& THIAGARAJAN, R., 2011. Interactive multimedia instruction versus traditional training programmes: Analysis of their effectiveness and perception. J. Agric. Educ. Ext., 17(5):459-472.

SHINN, Y.H., 1997. Teaching strategies, their use and effectiveness as perceived by teacher of agriculture: A national study. PhD Thesis, Iowa State University.

SIMPSON, B. \& OWENS, M., 2002. Farmer field schools and the future of agricultural extension in Africa. Paper presented to The 18th Annual Conference of the Association for International Agricultural and Extension Education. Durban, South Africa.

TERBLANCHÉ, S.E., 2013. Agricultural extension training needs of the non-government advising sector in South Africa. S. Afr. J. Agric. Ext., 41(1):94-106.

TRAIL, T.F., 1985. Recommendations for a strengthened extension program in Swaziland. Mbabane, Swaziland.

VANCLAY, F., 2004. Social principles for agricultural extension to assist in the promotion of natural resource management. Aust. J. Exp. Agric., 44(3):213-222. 
S. Afr. J. Agric. Ext.

Vol. 47 No. 3, 2019: 14 - 31

http://dx.doi.org/10.17159/2413-3221/2019/v47n3a512
Cloete, Bahta, Marunga \& Lombard (License: CC BY 4.0)

WORTH, S.H., 2007. The South African education agenda: Identifying markers for rewriting agricultural extension curricula. J. Agric. Educ. Ext., 13(2):131-145.

ZOSSOU, E., VAN MELE, P., VODOUHE, S.D. \& WANVOEKE, J., 2009. Comparing farmer-to-farmer video with workshops to train rural women in improved rice parboiling in central Benin. J. Agric. Educ. Ext., 15(4):329-339. 
